Prepared in cooperation with the Nevada Department of Conservation and Natural ResourcesDivision of Water Resources and the Las Vegas Valley Water District

\title{
Interferograms Showing Land Subsidence and Uplift in Las Vegas Valley, Nevada, 1992-99
}

Scientific Investigations Report 2006-5218 



\section{Interferograms Showing Land Subsidence and Uplift in Las Vegas Valley, Nevada, 1992-99}

By Michael T. Pavelko, Jörn Hoffmann, and Nancy A. Damar

Prepared in cooperation with the Nevada Department of Conservation and Natural Resources-Division of Water Resources and the Las Vegas Valley Water District

Scientific Investigations Report 2006-5218 


\section{U.S. Department of the Interior DIRK KEMPTHORNE, Secretary}

\section{U.S. Geological Survey \\ Mark D. Myers, Director}

\section{U.S. Geological Survey, Reston, Virginia: 2006}

For product and ordering information:

World Wide Web: http://www.usgs.gov/pubprod

Telephone: 1-888-ASK-USGS

For more information on the USGS--the Federal source for science about the Earth, its natural and living resources, natural hazards, and the environment:

World Wide Web: http://www.usgs.gov

Telephone: 1-888-ASK-USGS

Any use of trade, product, or firm names is for descriptive purposes only and does not imply endorsement by the U.S. Government.

Although this report is in the public domain, permission must be secured from the individual copyright owners to reproduce any copyrighted materials contained within this report.

Suggested citation:

Pavelko, M.T., Hoffmann, J., and Damar, N.A., 2006, Interferograms showing land subsidence and uplift in Las Vegas Valley, Nevada, 1992-99: U.S. Geological Survey Scientific Investigations Report 2006-5218, 17 p. 


\section{Contents}

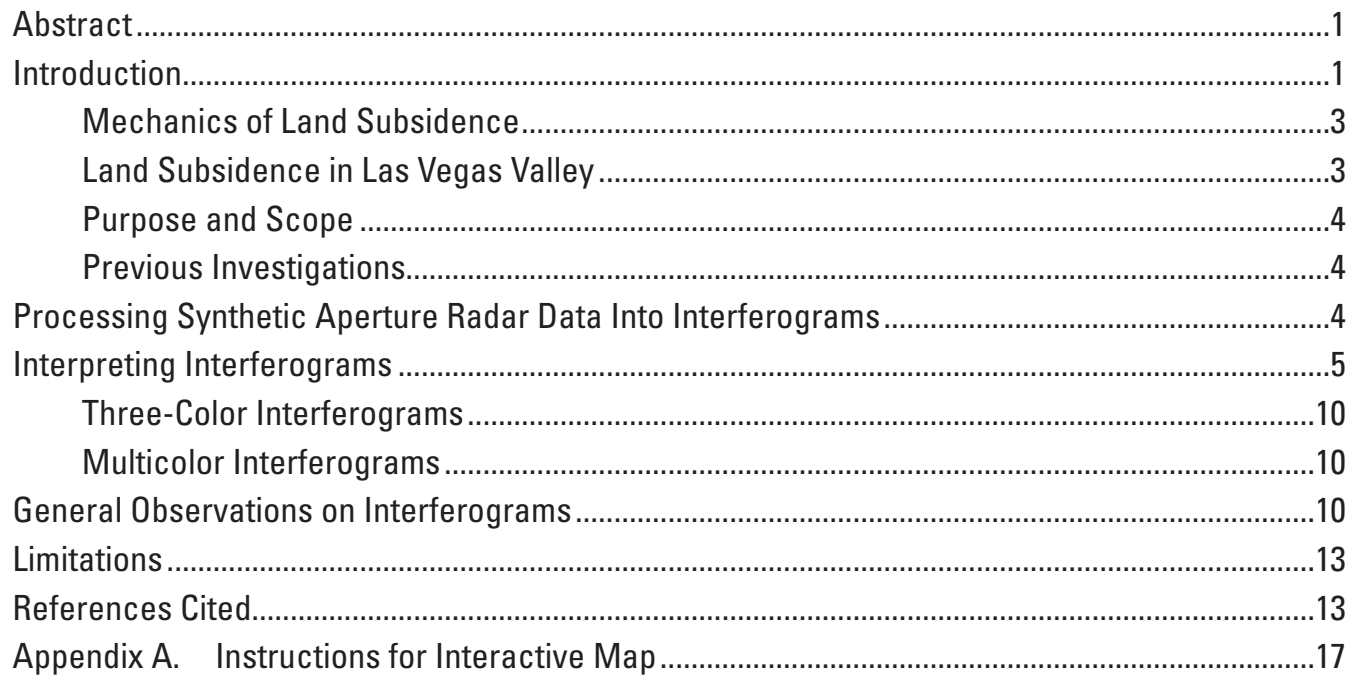

\section{Figures}

Figure 1. Landsat image showing location of Las Vegas Valley, Nevada, lines of equal land subsidence for 1963-2000, and the extent of the interferograms in

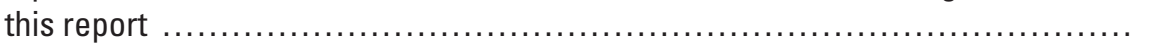

Figure 2. Example of $(A)$ multicolor and $(B)$ three-color interferograms for Las Vegas

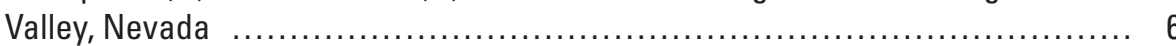

Figure 3. Stacked interferogram for Las Vegas Valley, Nevada, for September 8, 1992 to

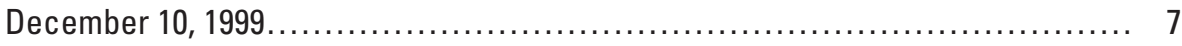

Figure 4. Landsat images of Las Vegas Valley, Nevada, $(A) 1993$ and $(B) 2000 \ldots \ldots \ldots \ldots \ldots \ldots . . . . .8$

Figure 5. (A) Multicolor interferogram with an area of temporal decorrelation and $(B)$ 2000 Landsat image, Las Vegas Valley, Nevada............................ 9

Figure 6. $(A)$ Multicolor and $(B)$ three-color interferograms with atmospheric phase

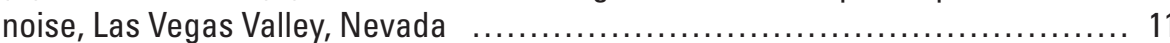

Figure 7. (A) Multicolor interferogram and $(B) 1993$ Landsat image, with subsidence bowls and areas with recurring localized displacement, Las Vegas Valley, Nevada 


\section{Tables}

Table 1. Dates, durations, and other information about the interferograms for Las Vegas

Valley, Nevada, 1992-99

\section{Conversion Factors}

SI to Inch/Pound

\begin{tabular}{lll}
\hline Multiply & \multicolumn{1}{c}{ By } & To obtain \\
\hline & Length & \\
\hline kilometer $(\mathrm{km})$ & 0.62137 & mile (mi) \\
meter $(\mathrm{m})$ & 3.281 & foot (ft) \\
millimeter $(\mathrm{mm})$ & 0.03937 & inch (in.) \\
\hline
\end{tabular}




\title{
Interferograms Showing Land Subsidence and Uplift in Las Vegas Valley, Nevada, 1992-99
}

\author{
By Michael T. Pavelko, Jörn Hoffmann, and Nancy A. Damar
}

\section{Abstract}

The U.S. Geological Survey, in cooperation with the Nevada Department of Conservation and Natural ResourcesDivision of Water Resources and the Las Vegas Valley Water District, compiled 44 individual interferograms and 1 stacked interferogram comprising 29 satellite synthetic aperture radar acquisitions of Las Vegas Valley, Nevada, from 1992 to 1999. The interferograms, which depict short-term, seasonal, and long-term trends in land subsidence and uplift, are viewable with an interactive map. The interferograms show that land subsidence and uplift generally occur in localized areas, are responsive to ground-water pumpage and artificial recharge, and, in part, are fault controlled. Information from these interferograms can be used by water and land managers to mitigate land subsidence and associated damage.

Land subsidence attributed to ground-water pumpage has been documented in Las Vegas Valley since the 1940s. Damage to roads, buildings, and other engineered structures has been associated with this land subsidence. Land uplift attributed to artificial recharge and reduced pumping has been documented since the 1990s. Measuring these land-surface changes with traditional benchmark and Global Positioning System surveys can be costly and time consuming, and results typically are spatially and temporally sparse. Interferograms are relatively inexpensive and provide temporal and spatial resolutions previously not achievable.

The interferograms are viewable with an interactive map. Landsat images from 1993 and 2000 are viewable for frames of reference to locate areas of interest and help determine land use. A stacked interferogram for 1992-99 is viewable to visualize the cumulative vertical displacement for the period represented by the individual interferograms. The interactive map enables users to identify and estimate the magnitude of vertical displacement, visually analyze deformation trends, and view interferograms and Landsat images side by side. The interferograms and Landsat images are available for download, in formats for use with Geographic Information System software.

\section{Introduction}

Land subsidence in Las Vegas Valley (fig. 1) was first recognized by comparing leveling surveys of benchmarks made between 1915 and 1935 (Maxey and Jameson, 1948). Subsidence continues to be measured with benchmark surveys, but the collection and continuity of these data have become jeopardized by rapid development destroying many of the benchmarks. Even with the addition of new benchmarks and Global Positioning System (GPS) technology, estimating subsidence rates and delineating valleywide subsidence patterns is difficult because of limited temporal data and a sparsely distributed benchmark network.

Satellite interferometric synthetic aperture radar (InSAR) data are capable of mapping spatially dense (20-90 m) deformation at temporal resolutions ranging from daily to monthly. A pair of synthetic aperture radar (SAR) images or scenes is used to develop an interferogram, which maps phase differences of radar waves reflected from the same location at different times. Phase differences can result from vertical and horizontal displacement associated with the deformation of the land surface and other conditions unrelated to deformation. During the processing of the interferograms described in this report, phase differences unrelated to deformation were minimized or eliminated, and all remaining phase differences were assumed to be the result of vertical displacement. InSAR technology and interferograms provide an effective and relatively inexpensive method for detecting and estimating sub-centimeter vertical deformation of the land surface at unprecedented spatial detail over large areas.

As part of a cooperative agreement with the Nevada Department of Conservation and Natural Resources-Division of Water Resources and the Las Vegas Valley Water District, the U.S. Geological Survey (USGS) has provided support for processing and analyzing interferograms and evaluated InSAR data for monitoring land subsidence and uplift in Las Vegas Valley. Personnel from Stanford University processed interferograms for Las Vegas Valley and personnel from the USGS, Stanford University, University of Hawaii, and Nevada Bureau of Mines and Geology analyzed them. The 44 individual interferograms presented in this report are for periods that range from 1.2 to 34.6 months between September 8, 1992, and December 10, 1999 (table 1). 


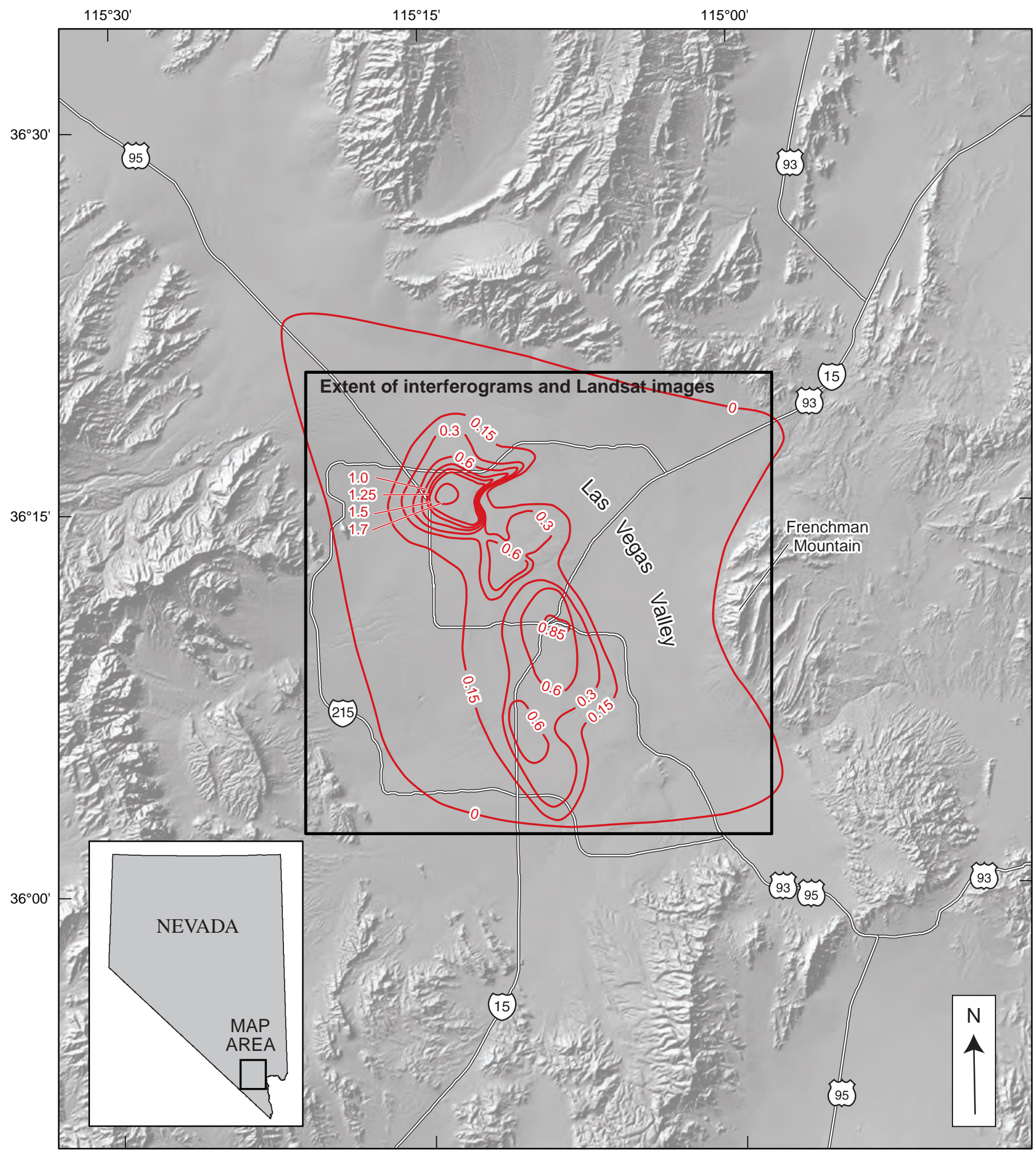

Base from U.S. Geological Survey digital data 1:100,000, 1978-89. Roads from Clark County, Nevada Street Centerline Database, 2006. Universal Transverse Mercator Projection, Zone 11, North American Datum of 1927. Shaded-relief base from 30-meter Digital Elevation Model; sun illumination from northwest at 30 degrees above horizon.

\section{EXPLANATION}

- 0.15 - Line of equal land subsidence-

Interval, in meters, is variable.

From Bell and others, 2002, fig. 10

Figure 1. Location of Las Vegas Valley, Nevada, lines of equal land subsidence for 1963-2000, and the extent of the interferograms in this report. 
Table 1. Dates, durations, and other information about the interferograms for Las Vegas Valley, Nevada, 1992-99.

[Interferogram numbers are used in appendix A. Span: RP, interferogram duration spans primarily months with decreased pumpage (January to April and October to December); IP, interferogram duration spans primarily months with increased pumpage (May to September). Deformation: A, interferogram is dominated by atmospheric phase noise; $\mathrm{B}$, deformation includes both subsidence and uplift; $\mathrm{S}$, majority of deformation in subsidence; $\mathrm{U}$, majority of deformation is uplift]

\begin{tabular}{|c|c|c|c|c|c|}
\hline \multirow{2}{*}{$\begin{array}{l}\text { Interfero- } \\
\text { gram No. }\end{array}$} & \multicolumn{2}{|c|}{ Acquisition dates } & \multirow{2}{*}{$\begin{array}{l}\text { Duration } \\
\text { (months) }\end{array}$} & \multirow{2}{*}{ Span } & \multirow{2}{*}{$\begin{array}{l}\text { Defor- } \\
\text { mation }\end{array}$} \\
\hline & Start & End & & & \\
\hline 1 & 09-08-92 & 04-06-93 & 7.0 & $\mathrm{RP}$ & $\mathrm{B}$ \\
\hline 2 & $03-02-93$ & $11-02-93$ & 8.3 & IP & $\mathrm{S}$ \\
\hline 3 & $04-06-93$ & $11-02-93$ & 7.0 & IP & $\mathrm{S}$ \\
\hline 4 & $04-06-93$ & $02-08-96$ & 34.6 & $\mathrm{RP}$ & $\mathrm{S}$ \\
\hline 5 & $11-02-93$ & 02-08-96 & 27.6 & $\mathrm{RP}$ & $\mathrm{B}$ \\
\hline 6 & $09-21-95$ & $11-30-95$ & 2.3 & $\mathrm{RP}$ & $\mathrm{U}$ \\
\hline 7 & $09-21-95$ & $05-24-96$ & 8.2 & $\mathrm{RP}$ & $\mathrm{B}$ \\
\hline 8 & $09-21-95$ & $05-09-97$ & 19.1 & $\mathrm{RP}$ & $\mathrm{U}$ \\
\hline 9 & $11-30-95$ & $05-24-96$ & 5.9 & $\mathrm{RP}$ & $\mathrm{B}$ \\
\hline 10 & $11-30-95$ & 05-09-97 & 17.5 & $\mathrm{RP}$ & $\mathrm{B}$ \\
\hline 11 & 01-04-96 & $05-24-96$ & 4.7 & $\mathrm{RP}$ & $\mathrm{S}$ \\
\hline 12 & $01-04-96$ & $01-24-97$ & 12.9 & $\mathrm{RP}$ & $\mathrm{S}$ \\
\hline 13 & $01-04-96$ & 04-24-98 & 28.0 & $\mathrm{RP}$ & $\mathrm{B}$ \\
\hline 14 & $02-08-96$ & 04-04-97 & 14.0 & $\mathrm{RP}$ & $\mathrm{S}$ \\
\hline 15 & $05-24-96$ & $10-11-96$ & 4.7 & IP & $\mathrm{S}$ \\
\hline 16 & $05-24-96$ & $05-09-97$ & 11.7 & $\mathrm{RP}$ & B \\
\hline 17 & 08-02-96 & $05-09-97$ & 9.3 & $\mathrm{RP}$ & B \\
\hline 18 & $10-11-96$ & $05-09-97$ & 7.0 & $\mathrm{RP}$ & $\mathrm{U}$ \\
\hline 19 & $12-20-96$ & $05-09-97$ & 4.7 & $\mathrm{RP}$ & $\mathrm{U}$ \\
\hline 20 & $01-24-97$ & 04-04-97 & 2.3 & $\mathrm{RP}$ & B \\
\hline 21 & $01-24-97$ & $05-09-97$ & 3.5 & $\mathrm{RP}$ & B \\
\hline 22 & $02-28-97$ & 05-09-97 & 2.3 & $\mathrm{RP}$ & B \\
\hline 23 & 04-04-97 & $08-22-97$ & 4.7 & IP & $\mathrm{S}$ \\
\hline 24 & 04-04-97 & $04-24-98$ & 12.8 & $\mathrm{RP}$ & B \\
\hline 25 & 05-09-97 & 06-13-97 & 1.2 & IP & A \\
\hline 26 & 05-09-97 & 07-18-97 & 2.3 & IP & A \\
\hline 27 & $05-09-97$ & $09-26-97$ & 4.7 & IP & $\mathrm{S}$ \\
\hline 28 & $05-09-97$ & $12-05-97$ & 7.0 & IP & $\mathrm{S}$ \\
\hline 29 & $05-09-97$ & 01-09-98 & 8.2 & IP & $\mathrm{S}$ \\
\hline 30 & 05-09-97 & $02-13-98$ & 9.3 & IP & B \\
\hline 31 & $05-09-97$ & 03-20-98 & 10.5 & $\mathrm{RP}$ & $\mathrm{B}$ \\
\hline 32 & $05-09-97$ & $05-29-98$ & 12.8 & $\mathrm{RP}$ & $\mathrm{B}$ \\
\hline 33 & $05-09-97$ & 01-29-99 & 21.0 & $\mathrm{RP}$ & $\mathrm{B}$ \\
\hline 34 & 05-09-97 & $12-10-99$ & 31.5 & $\mathrm{RP}$ & $\mathrm{S}$ \\
\hline 35 & 07-18-97 & $04-24-98$ & 9.3 & $\mathrm{RP}$ & $\mathrm{U}$ \\
\hline 36 & $08-22-97$ & $04-24-98$ & 8.2 & $\mathrm{RP}$ & $\mathrm{U}$ \\
\hline 37 & 09-26-97 & $12-05-97$ & 2.3 & $\mathrm{RP}$ & $\mathrm{B}$ \\
\hline 38 & 09-26-97 & 04-24-98 & 7.0 & $\mathrm{RP}$ & $\mathrm{U}$ \\
\hline 39 & $09-26-97$ & 01-29-99 & 16.3 & $\mathrm{RP}$ & $\mathrm{B}$ \\
\hline 40 & $12-05-97$ & 04-24-98 & 4.7 & $\mathrm{RP}$ & $\mathrm{U}$ \\
\hline 41 & $04-24-98$ & 01-29-99 & 9.3 & IP & $\mathrm{S}$ \\
\hline 42 & 04-24-98 & $10-01-99$ & 17.5 & IP & $\mathrm{S}$ \\
\hline 43 & $05-29-98$ & 01-29-99 & 8.2 & $\mathrm{RP}$ & A \\
\hline 44 & 01-29-99 & $12-10-99$ & 10.5 & $\mathrm{RP}$ & $\mathrm{S}$ \\
\hline
\end{tabular}

The stacked interferogram is a composite of 8 time-sequential interferograms that span the same range of dates as the 44 individual interferograms. The analyses indicate that subsidence rates generally are lower than rates measured before 1991 (Bell and others, 2000; 2002), geologic faults influence patterns of land subsidence (Amelung and others, 1999; Bell and others, 2000), and seasonal uplift occurs in many areas across the valley (Hoffmann and others, 2001; Hoffmann, 2003).

\section{Mechanics of Land Subsidence}

Land subsidence in Las Vegas Valley results from compaction of fine-grained sediments (silt and clay) within the basin-fill aquifer system (Maxey and Jameson, 1948; Malmberg, 1965; Bell, 1981). This compaction results from an increase in effective stress within the aquifer system resulting from lower water levels caused by pumping ground water (Terzaghi, 1925; 1943). In addition to compaction resulting from ground-water pumpage, seasonal water-level fluctuations associated with natural processes and groundwater-use practices have resulted in corresponding fluctuations in vertical deformation of the aquifer-system (Pavelko, 2000). Detailed and technical discussions about the relations between water-level fluctuations and aquifer-system stress and deformation are in Tolman and Poland (1940), Poland (1960), and Riley (1969).

\section{Land Subsidence in Las Vegas Valley}

Land subsidence has been a concern in Las Vegas Valley since Maxey and Jameson (1948) first recognized its occurrence. Surveys of various regional and local networks indicated that subsidence occurred at a relatively slow, steady rate throughout large regions of the valley into the mid-1960s. Subsidence rates increased throughout the late 1960s to the 1980s, forming localized subsidence bowls within a larger regional area of subsidence (fig. 1). The deepest localized bowl subsided more than $1.7 \mathrm{~m}$ as of 2000 , and the other bowls subsided more than $0.6 \mathrm{~m}$ (Bell, 1981; Bell and Price, 1993; Bell and others, 2000; 2002).

Land subsidence has resulted in damage to wells, homes, roads, and water lines in Las Vegas Valley (Mindling, 1971; Bell, 1981, 1997; Bell and Price, 1993). Since the 1990s, land-subsidence rates have decreased (Bell and others, 2000) as water levels across the valley have remained stable or have risen. Artificial ground-water recharge programs, implemented by the Las Vegas Valley Water District and the City of North Las Vegas, have contributed to stable and rising water levels; also, land uplift has occurred in some areas (Bell and others, 2000). Increasing ground-water demands from a growing population in Las Vegas Valley could result in lower water levels and, ultimately, an increase in land-subsidence rates throughout the valley. 


\section{Purpose and Scope}

This report allows for viewing and downloading interferograms and Landsat images for Las Vegas Valley, Nev. The interferograms demonstrate the value of InSAR technology to delineate land-subsidence and uplift patterns and trends. Thus, interferograms could assist water and land mangers in mitigating land subsidence and associated damage. The general approach used to develop the interferograms and selected observations pertinent to water-use and landdeformation studies are described herein.

SAR data were processed into individual interferograms where, for purposes of visualization, displacements are scaled differently using a multicolor and a three-color sequence. The multicolor scaling accentuates smaller-scale displacement and the three-color scaling accentuates areas of displacement. The interferograms depict deformation for 44 time intervals ranging from 1.2 to 34.6 months between September 8, 1992, and December 10, 1999 (table 1). A stacked interferogram created from 8 time-sequential interferograms spans the same dates as the individual interferograms. The European Space Agency's Earth Remote Sensing satellites (ERS-1 and ERS-2), which began collecting SAR data for the Las Vegas area in 1992, acquired the SAR data used to create the interferograms. National Aeronautics and Space Administration's Landsat 5 and 7 satellites acquired the Landsat images in 1993 and 2000, respectively.

The interferograms and the Landsat images are viewable in appendix A using an interactive map designed for sideby-side comparisons, and are available for download for use with Geographic Information Systems (GIS) software. The three-color individual and stacked interferograms available for download are in a grid format and the multicolor interferograms and Landsat images are georeferenced tiff images. The Landsat images provide a frame of reference for the interferograms. The extent of figures $2-7$ and all appendix A images in the interactive map is shown in figure 1; the extent of the images available for download is larger than those in the report and appendix A.

\section{Previous Investigations}

Amelung and others (1999) measured land subsidence and uplift in Las Vegas Valley using interferometry and noted that faults and the thickness of clay units, in part, control the areal distribution of land subsidence. Bell and others (2000; 2002) examined InSAR, GPS, and past benchmarksurvey data and noted that subsidence in Las Vegas Valley is localized more than was believed previously and that land-subsidence rates generally have decreased since 1991 . Based on this information, previously constructed subsidence contours for 1963-87 (Bell and Price, 1993) were modified and updated (Bell and others, 2000, 2002). Hoffmann and others (2001) used interferometry to measure seasonal land subsidence and uplift, and ground-water level data at selected monitor-well sites to estimate aquifer-system elastic storage coefficients. Hoffmann (2003) investigated the application of interferometric techniques to the measurement and interpretation of vertical deformation over pumped aquifers, including a detailed description of methods and procedures and a Las Vegas Valley case study.

Other studies that used InSAR to map subsidence and (or) uplift attributed to ground-water level changes in areas outside of Las Vegas Valley, Nev., include investigations in Albuquerque Basin, New Mex. (Heywood and others, 2002), Antelope Valley, Calif. (Galloway and others, 1998; Hoffmann and others, 2003); San Luis Obispo County, Calif. (Valentine and others, 2001); Coachella Valley, Calif. (Sneed and others, 2001; 2002); Houston-Galveston Bay area, Tex. (Stork and Sneed, 2002; Buckley and others, 2003); Santa Ana Basin, Calif. (Bawden and others, 2001), Santa Clara Valley, Calif. (Ikehara and others, 1998; Schmidt and Bürgmann, 2003), and Yucca Flat, Nev. (Laczniak and others, 2003; Halford and others, 2005). Galloway and others (2000) provide a general overview of measuring land subsidence using interferometric techniques.

Interferometry has been used for high-density spatial mapping of ground-surface deformation associated with tectonic (Massonnet and others, 1993; Zebker and others, 1994; Bawden and others, 2001) and volcanic strains (Massonnet and others, 1995; Rosen and others, 1996; Wicks and others, 1998). InSAR has been used to map localized crustal deformation and land subsidence associated with geothermal fields in Imperial Valley, California (Massonnet and others, 1997), Long Valley, Calif. (Thatcher and Massonet, 1997), and Iceland (Vadon and Sigmundsson, 1997), and with oil and gas fields in the Central Valley, Calif. (Fielding and others, 1998).

\section{Processing Synthetic Aperture Radar Data Into Interferograms}

These interferograms were developed from paired satellite SAR images that were processed to estimate vertical displacement. SAR emits pulses of microwaves along a track of the satellite's orbit and receives reflected waves from the Earth's surface. Specialized processing routines account for the forward motion of the satellite and allow for higher resolution images than traditional (unfocused) radar.

The phase components of reflected waves from two data acquisitions are differenced and processed to form interferograms, which are phase-difference maps (see "Limitations" section). Phase differences are caused by (1) displacement or motion between the satellite and reflectors 
on the Earth's surface that occurs between data acquisitions; (2) viewing the Earth from two slightly different angles (satellite orbital geometry); (3) changes in atmospheric conditions; and (4) decorrelation or noise (Zebker and others, 1994, and Ferretti and others, 2000). The goal of processing interferograms for studies of land deformation is to accentuate phase differences resulting from changes in the land-surface position and minimize all other phase differences. Based on the assumption of zero horizontal deformation, the phasedifference data are projected into assumed vertical changes in reflector height and then smoothed. The computed vertical changes were referenced to the same small area, assumed stable for all the interferograms, by subtracting the mean vertical change of the stable area from the computed vertical changes.

The phase differences are measured in the repeating interval from zero to $2 \pi$, where every $2 \pi$ cycle is equivalent to a line-of-sight change equal to one-half the radar wavelength, which is about $28 \mathrm{~mm}$ for SAR data collected by ERS satellites. The phase-difference data are unwrapped (Costantini, 1998; Chen, 2001) to create an unwrapped interferogram that represents a continuous surface of absolute displacement values. Vertical displacement can be estimated with an accuracy of about $5 \mathrm{~mm}$ for each $4 \times 40 \mathrm{~m}$ interferogram pixel by using stable reflectors such as buildings, roads, or undisturbed ground surfaces, and under favorable atmospheric conditions. The stacked interferogram is a summation of the time-sequential individual interferograms $1,3,5,14,23,36,41$, and 44 (table 1).

For this report, each interferogram is unwrapped and presented using different color schemes (figs. 2 and $\underline{3}$ ). Three-color individual interferograms depict uplift (purple), no displacement (yellow), and subsidence (green), for a range of $224 \mathrm{~mm}$ of vertical displacement, whereas the three-color stacked interferogram depicts uplift (blue), no displacement (yellow), and subsidence (red), for a range of $448 \mathrm{~mm}$ of vertical displacement. Multicolor interferograms have a repeating, five-color sequence, where each sequence represents $20 \mathrm{~mm}$ of vertical displacement. The order of the colors indicates subsidence (blue-green-yellow-orange-red) or uplift (red-orange-yellow-green-blue).

Additional background on interferometry methodology is in Gabriel and others (1989), Massonnet and Feigl (1998), and Hanssen (2001); a comprehensive presentation of SAR image processing is in Curlander and McDonough (1991). Galloway and others (1998) and Hoffmann (2003) provide more intensive discussions about interferometric applications for the study of land subsidence attributed to ground-water development. The limitations of interferometry and phase measurement are discussed in the "Limitations" section of this report.

\section{Interpreting Interferograms}

The individual interferograms represent vertical displacement that occurred between SAR data acquisitions (table 1) and the stacked interferogram represents vertical displacement that occurred from September 8, 1992, to December 10, 1999. There is a three-color and a multicolor interferogram for each individual period, whereas there is only a three-color stacked interferogram. The deformation represented in the interferograms depicts altitude changes relative to a point of assumed zero vertical displacement; zero horizontal displacement is assumed.

The Landsat images (fig. 4), acquired in 1993 (Landsat 5) and 2000 (Landsat 7), provide a spatial reference for the interferograms, indicate land use, and, when compared, they show urban development between 1993 and 2000. The Landsat images are presented with the near-infrared, red, and green bands (4, 3, and 2, respectively) colored red, green, and blue, respectively. With this coloration, red is indicative of healthy growing vegetation, black indicates open water, and gray or white indicates bare soil.

To determine areas of deformation and amounts of vertical displacement for a given period, it is advantageous to examine both types of individual interferograms. Threecolor interferograms typically are better for identifying areas of deformation, delineating large deformation patterns, and estimating the amount of displacement. Multicolor interferograms typically are better for estimating relative displacement, identifying decorrelated areas, and delineating localized deformation patterns. Displacement measurements and deformation patterns cannot be estimated for decorrelated areas and should be estimated with caution where atmospheric phase noise is suspected (see "Limitations" section).

Temporal decorrelation may result from the relative movement of reflectors within a radar-resolution cell and often is associated with the movement of vegetation parts (leaves, twigs), vegetation growth or removal, changes in soil moisture, erosion, and, commonly in Las Vegas Valley, urban development. Decorrelated areas are pixilated in interferograms, appearing as a range of stippled colors, and more easily identified in multicolor interferograms than in three-color interferograms (fig. 5). Temporal decorrelation in the Las Vegas Valley interferograms typically is limited to small areas, thus the remainder of the interferogram can be evaluated. Golf courses, easily identified as red areas in the Landsat images (fig. 5B ), commonly are associated with temporal decorrelation, likely resulting from plant growth, landscaping changes, or watering practices. 

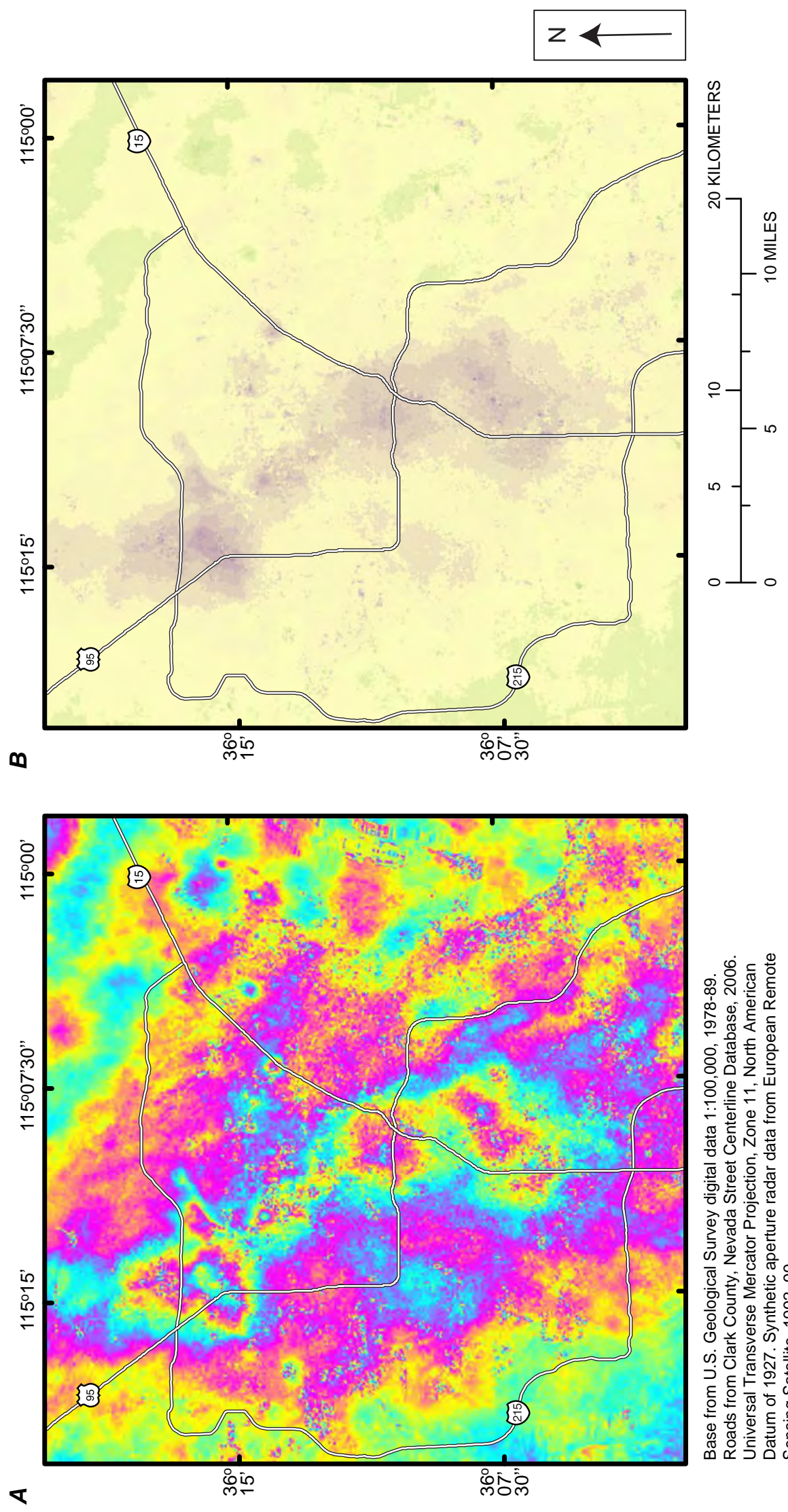

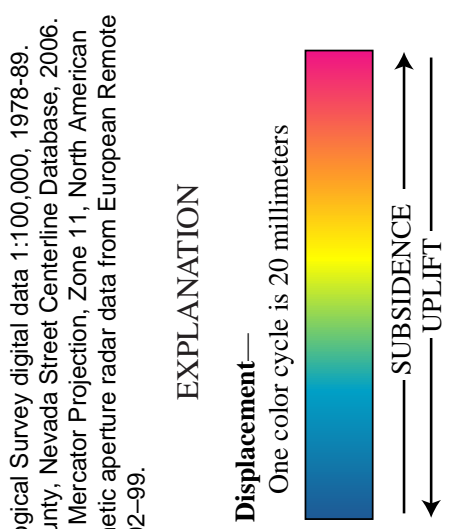

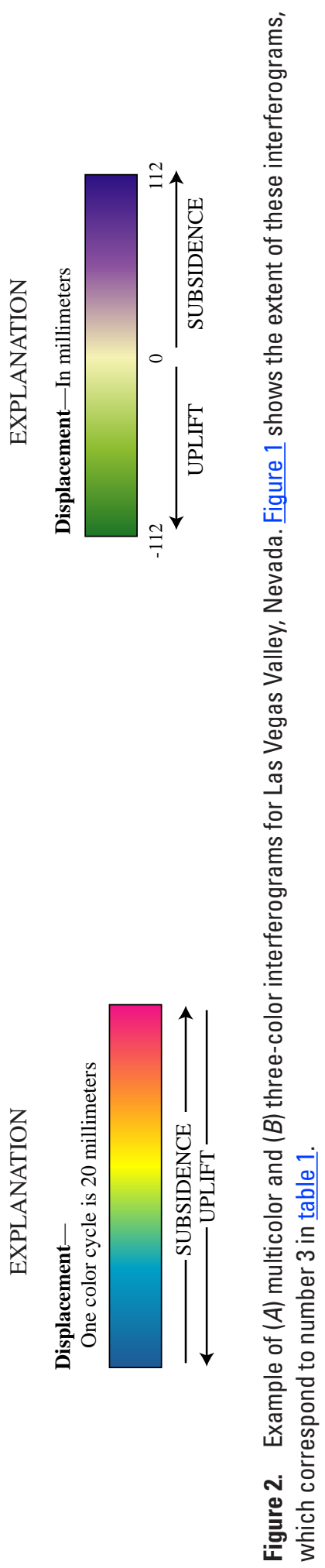




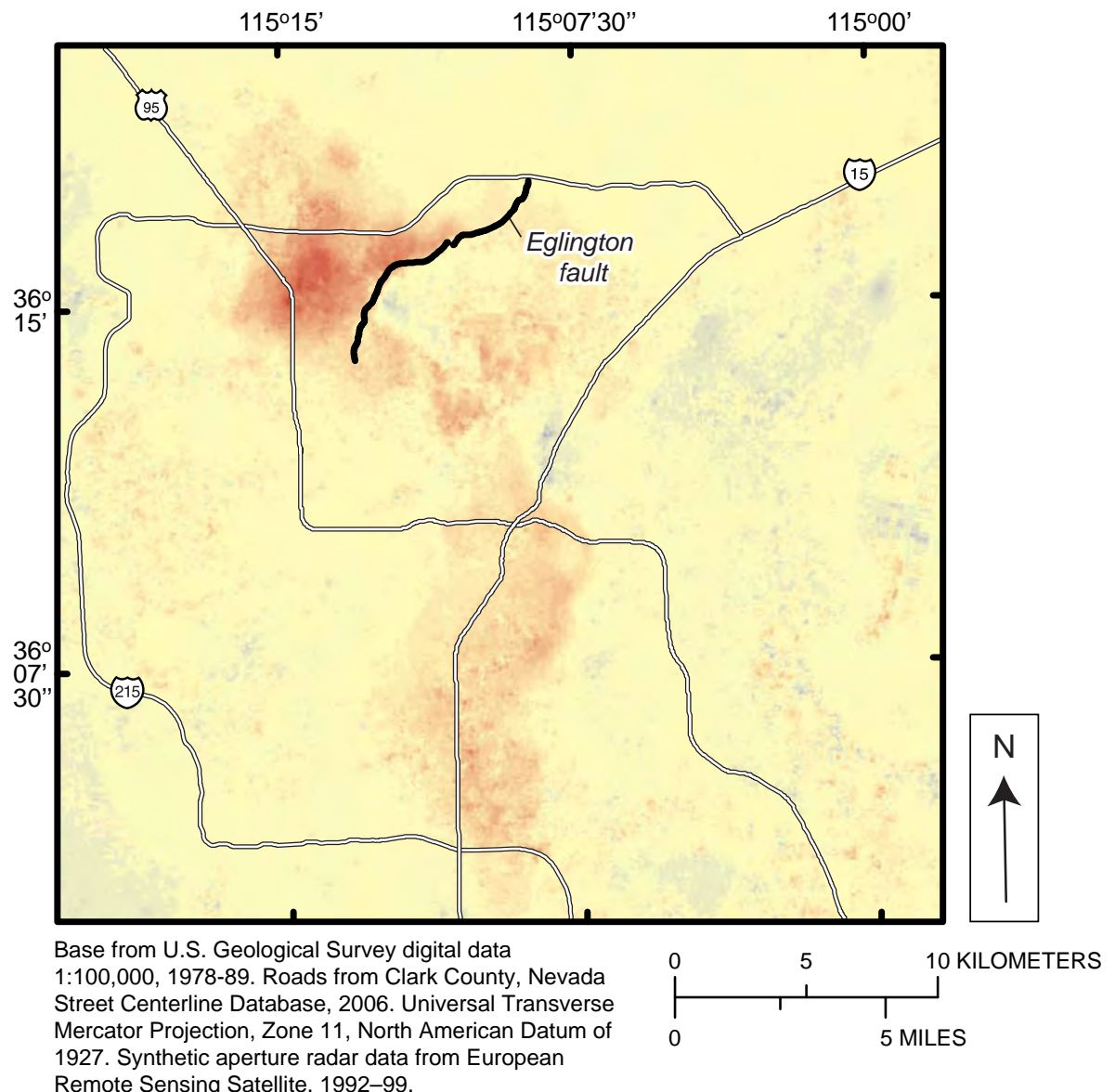

EXPLANATION

Displacement—In millimeters

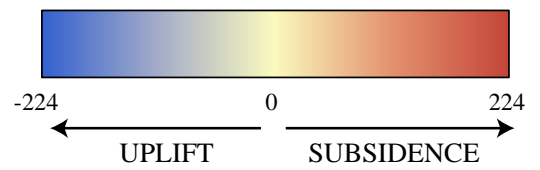

Figure 3. Stacked interferogram for Las Vegas Valley, Nevada, for September 8, 1992 to December 10, 1999. Figure 1 shows the extent of the interferogram. 

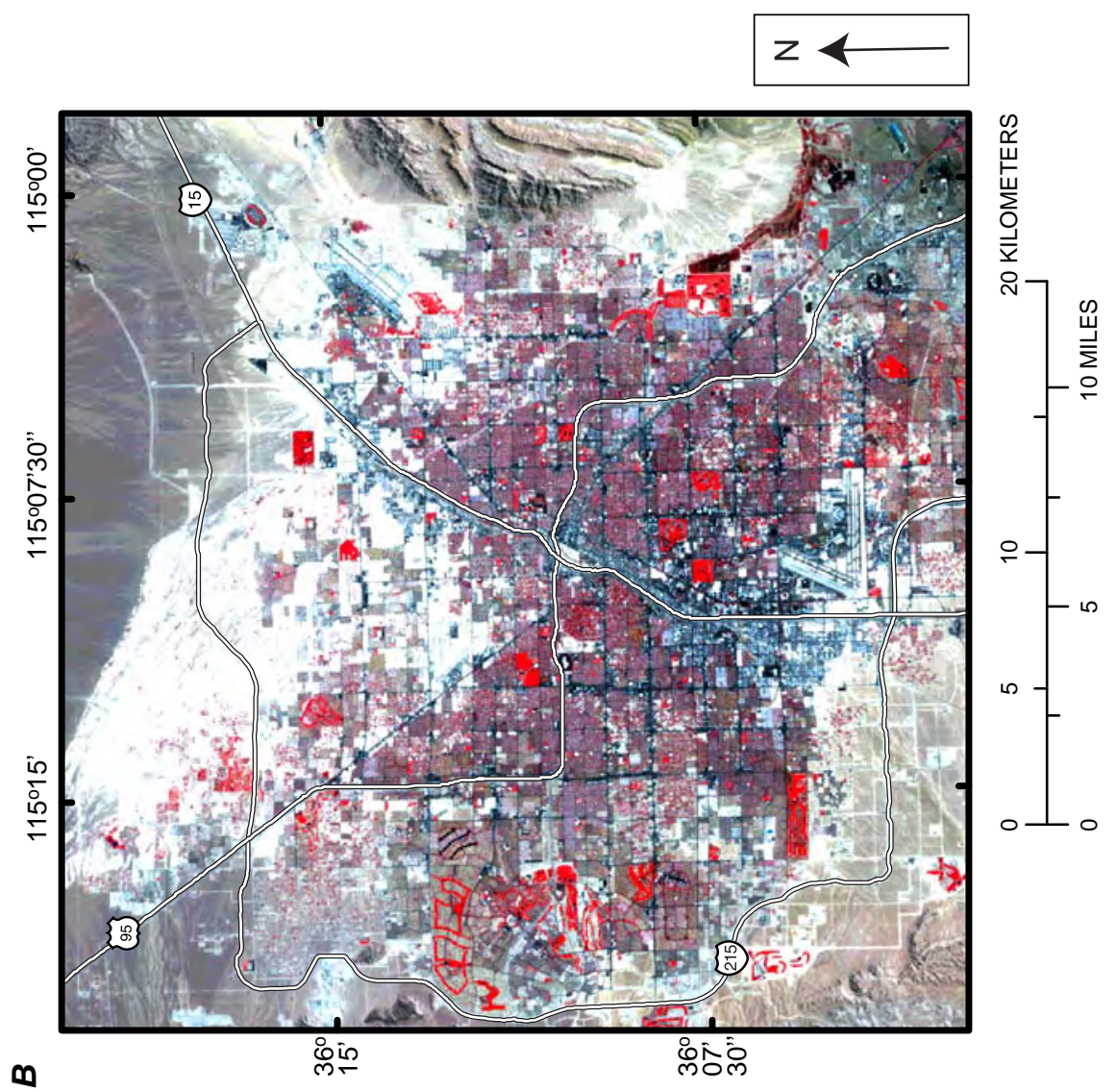

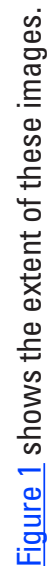

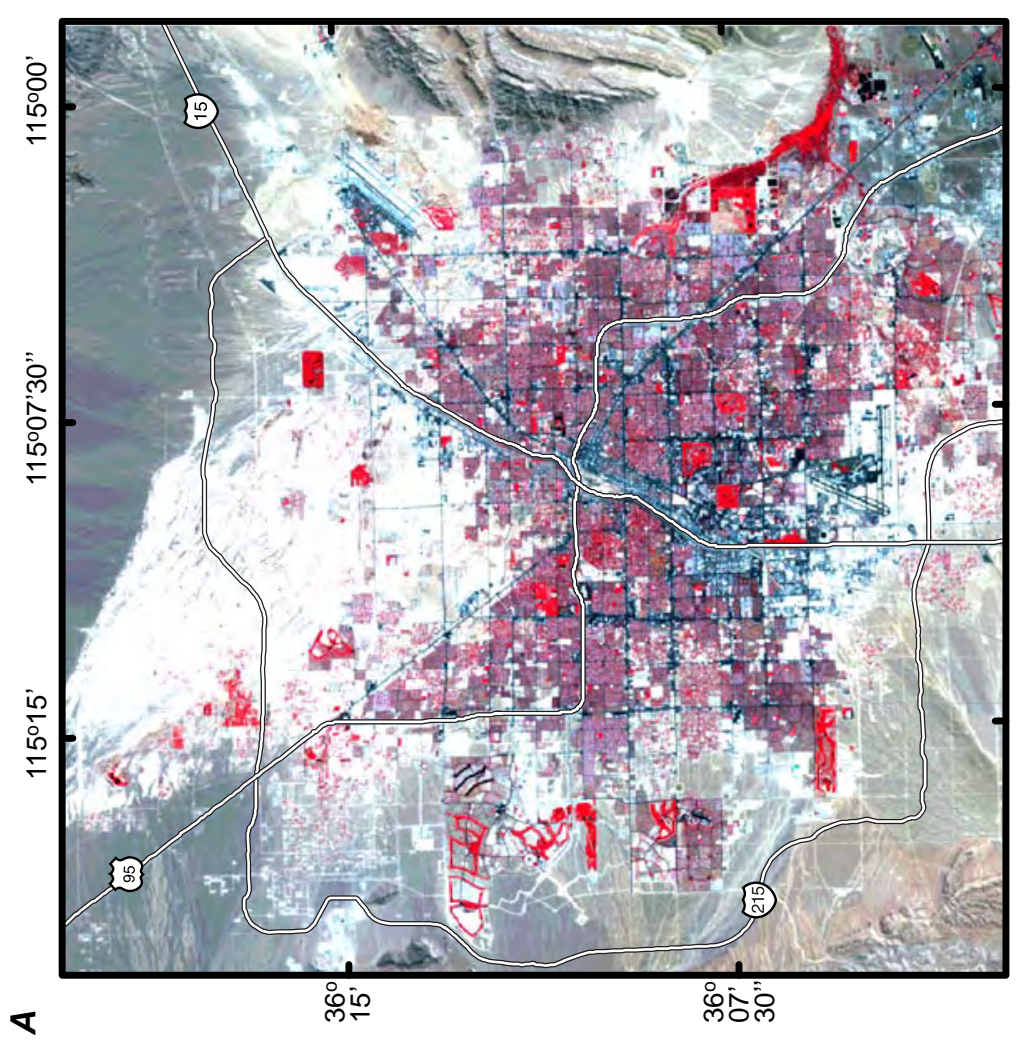

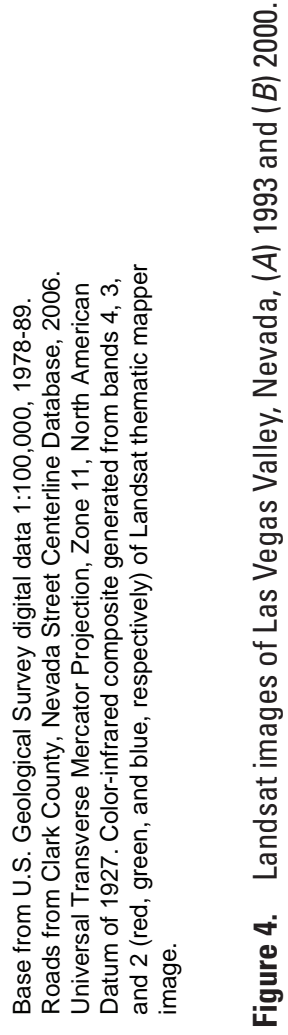




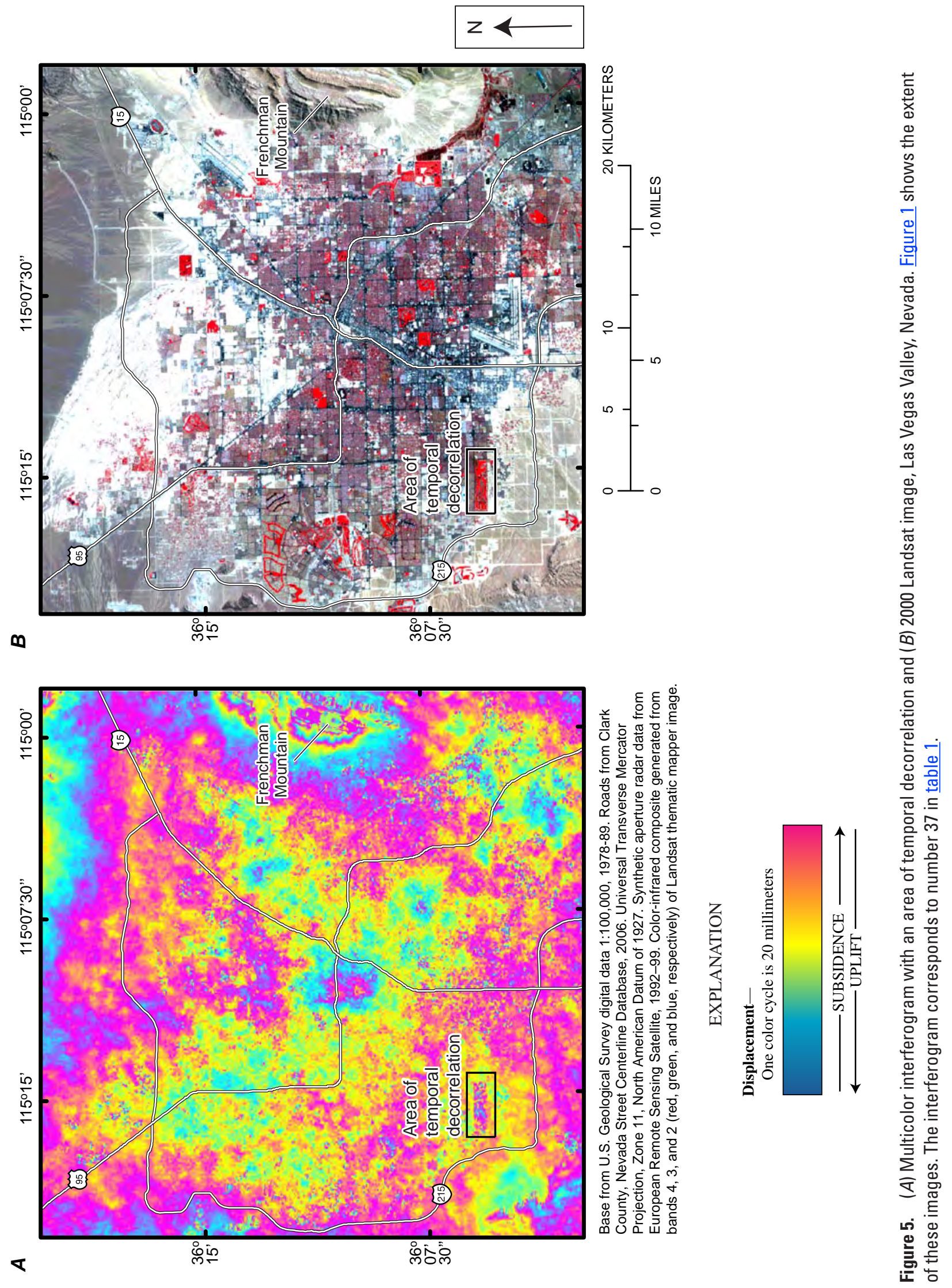


Atmospheric phase noise results from changes in atmospheric conditions between data acquisitions and, therefore, occurs to varying degrees in all interferograms. Thus, all interferograms should be interpreted with caution because atmospheric phase noise can modulate displacement signals. Atmospheric effects can be difficult to identify because they can occur across an entire interferogram and can resemble deformation patterns. The location, shape, and magnitude of the noise is assumed unique to specific acquisition dates, thus if atmospheric effects are suspected in an interferogram, other interferograms with a common acquisition date should have similar noise patterns. Because land-subsidence and uplift trends in Las Vegas Valley typically have annual cycles (Pavelko, 2000; Hoffmann and others, 2001) but atmospheric phase noise usually is associated with specific acquisition dates, careful examination and comparison of multiple interferograms can assist in determining whether a pattern is the result of deformation or other phase noise. As a rule of thumb for these Las Vegas Valley interferograms, patterns that annually repeat typically are the result of land deformation and patterns that appear only in interferograms with common acquisition dates typically are the result of phase noise. For example, interferograms with an acquisition date of May 29, 1998, display phase noise likely related to atmospheric moisture changes (fig. 6; table 1).

\section{Three-Color Interferograms}

The individual three-color interferograms depict $224 \mathrm{~mm}$ of vertical displacement with a gradational color scheme that ranges from purple (subsidence) to yellow (minimal or no displacement) to green (uplift; fig. 2) and the stacked interferogram depicts $448 \mathrm{~mm}$ of vertical displacement that ranges from red (subsidence) to yellow (minimal or no displacement) to blue (uplift; fig. 3). Deforming areas and deformation patterns are relatively easy to identify by noting the location and shapes of darker purple and darker green areas for individual interferograms and darker red and darker blue areas for stacked interferograms. The color-scale bars show the magnitude of displacement.

\section{Multicolor Interferograms}

Multicolor interferograms depict displacement with a repeating color sequence (fig. 2). One continuous sequence of colors represents $20 \mathrm{~mm}$ of displacement. Within a color sequence, any single color with a continuous and arcuate or linear pattern is analogous to a displacement contour. The order of colors indicates whether deformation is subsidence or uplift, as shown in the color-scale bar.

Displacement should be estimated only for areas with well-defined partial, full, or multiple sets of colors that are surrounded by or adjacent to areas with no displacement.
Generally, broad areas of one color are areas with no displacement. The estimated displacement is relative only to the adjacent area and is not necessarily the total amount of displacement. Relative displacement is estimated by noting the colors between the area of interest and the adjacent area. If the colors are not a full sequence, use the color-scale bar to estimate the relative displacement. If the colors include one or more sequences, assign $20 \mathrm{~mm}$ of displacement to each full sequence, treat any remaining partial sequence as above, and add the estimated partial-sequence amount to the full-sequence amount.

Multicolor interferograms typically are better than threecolor interferograms for identifying decorrelated areas because the color contrast between decorrelated and correlated areas is higher in multicolor interferograms. Localized deformation patterns typically are easier to delineate in multicolor interferograms because $20 \mathrm{~mm}$ of displacement is represented by multiple colors, whereas for three-color interferograms, $224 \mathrm{~mm}$ of displacement is represented by only three colors (fig. 2).

\section{General Observations on Interferograms}

These interferograms reveal regional (valleywide) and localized land subsidence and uplift patterns. The most obvious deformation feature is the northwest subsidence bowl and its proximity to the Eglington fault (figs. 3 and 7; Amelung and others, 1999; Bell and others, 2000). Deformation is persistent along the north-south axis of the valley, but the remaining subsidence bowls are less defined than the northwest bowl (fig. 7). Generally, individual interferograms that predominately span months of increased pumpage (May-September) have patterns dominated by land subsidence (interferograms 2, 3, 15, 23, 27, 28, 29, 41, and 42 ; table 1) and interferograms that predominately span months of decreased pumpage or artificial recharge have more complex deformation patterns that include regional or local uplift (Hoffmann and others, 2001; Hoffmann, 2003). For interferograms that span mostly months of decreased pumpage, 8 predominantly have uplift (interferograms 6,8 , $18,19,35,36,38$, and 40), 6 predominantly have subsidence (interferograms 4, 11, 12, 14, 34, and 44), and 17 have both subsidence and uplift (interferograms 1, 5, 7, 9, 10, 13, 16, $17,20,21,22,24,31,32,33,37$, and 39). Generally, land uplift does not occur within the northwestern subsidence bowl. Recurring, localized deformation features (fig. 7) generally appear in the northeastern part of the valley and are more easily identified on multicolor interferograms than three-color interferograms. The stacked interferogram shows that from September 8, 1992 to December 10, 1999, the predominant type of vertical displacement was subsidence. 

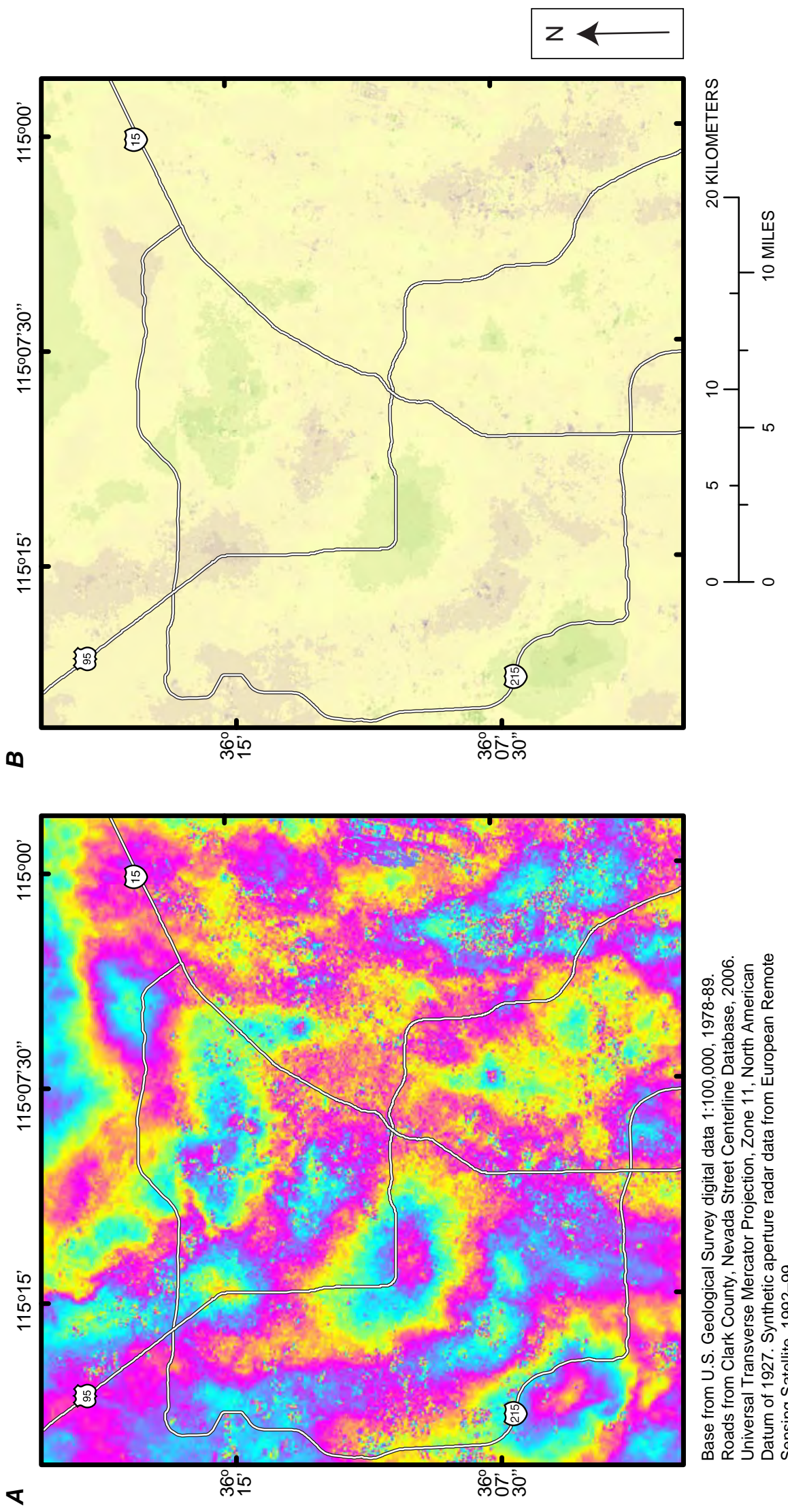

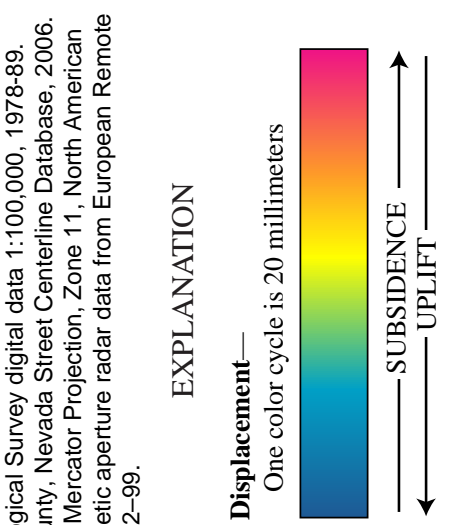

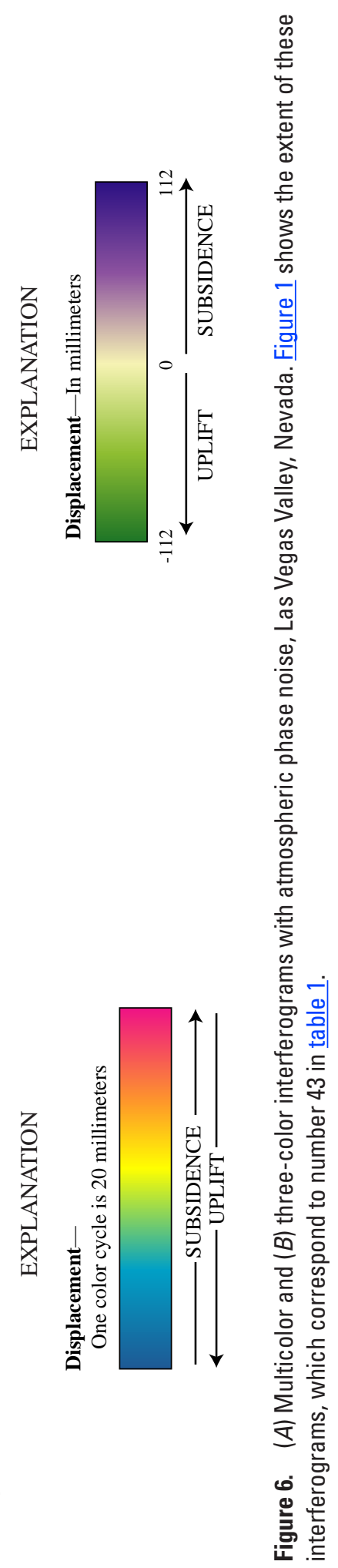



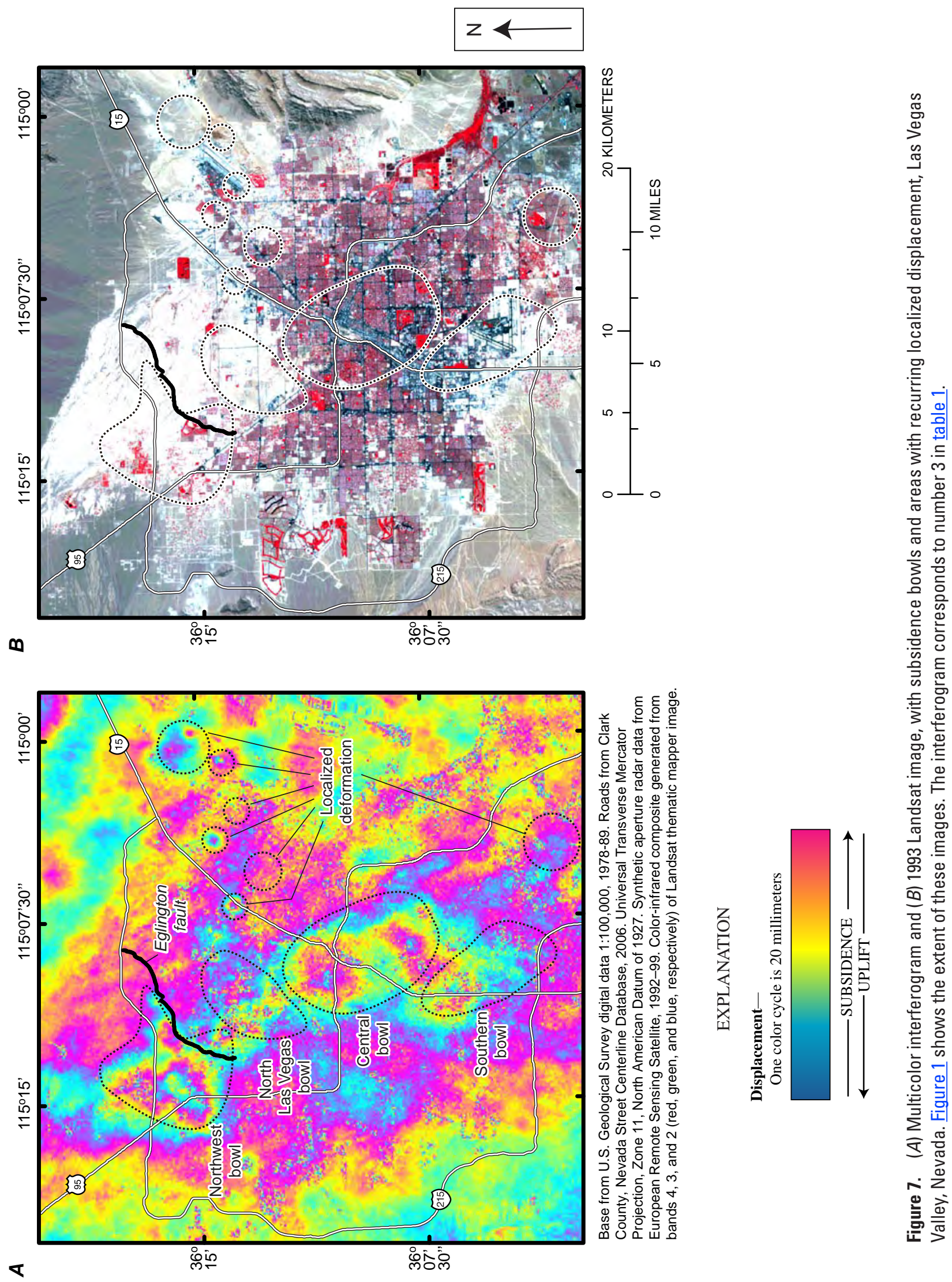


\section{Limitations}

The colors and patterns of these interferograms, or phasedifference maps, result from ground-surface deformation, different satellite positions during data acquisitions, different atmospheric conditions, and decorrelation or noise (Zebker and others, 1994; Ferretti and others, 2000). Phase changes due to different satellite positions have been corrected in these interferograms. The remaining phase changes not related to ground-surface deformation are considered phase noise for the purposes of land-deformation studies. Although the processing of these interferograms focused on accentuating phase differences resulting from ground-surface deformation and minimizing phase noise, some phase noise persists in the interferograms.

For land-deformation studies, interferometric results are best for relatively flat ground surfaces, such as the floor of Las Vegas Valley. Digital elevation-data errors, which often are present for steep terrain, and orographic effects can affect phase-difference data for steep slopes and high mountains. For this reason, interferometric patterns that appear near and on Frenchman Mountain, such as those in figure 5A, should not be included in deformation analyses, as these patterns likely are not the result of land deformation.

Limitations associated with the acquisition and processing of SAR data also include (1) the temporal resolution of interferometry is dependent on satellite stability/ repeatability, (2) deformation depicted within an interferogram pixel is an average of the true deformation distributed across the land surface represented by the pixel, (3) algorithms used to unwrap SAR data are not 100-percent accurate, and (4) processing raw SAR data into interferograms is complex and requires a specialist. A limitation that arises from a simplifying assumption is that phase differences attributed to deformation are assumed to be purely vertical (zero horizontal deformation is assumed).

The limitations of interferometric measurements of landsurface deformation are complex and a detailed discussion is beyond the scope of this report. Hoffmann (2003) provides a more detailed discussion of the SAR-data acquisition, processing, and limitations of the interferograms presented in this report. Jónsson (2002) provides a more thorough discussion of errors and biases associated with interferometricphase measurements and Hanssen (2001) provides a comprehensive discussion of errors associated with radar interferometry.

\section{References Cited}

Amelung, Falk, Galloway, D.L., Bell, J.W., Zebker, H.A., and Laczniak, R.J., 1999, Sensing the ups and downs of Las Vegas: InSAR reveals structural control of land subsidence and aquifer-system deformation: Geology, v. 27, no. 6, p. 483-486.
Bawden, G.W., Thatcher, Wayne, Stein, R.S., Hudnut, K.W., and Peltzer, Gilles, 2001, Tectonic contraction across Los Angeles after removal of groundwater pumping effects: Nature, v. 412, p. 812-815.

Bell, J.W., 1981, Subsidence in Las Vegas Valley: Nevada Bureau of Mines and Geology Bulletin 95, 84 p.

Bell, J.W., 1997, Las Vegas Valley: Land subsidence and fissuring due to ground-water withdrawal: U.S. Geological Survey, last accessed September 2006 at: http://geochange. er.usgs.gov/sw/impacts/hydrology/vegas gw/.

Bell, J.W., Amelung, Falk, and Ramelli, A.R., 2000, Land subsidence in Las Vegas, Nevada, USA: New geodetic data reveal localized spatial patterns, structural controls, and reduced rates, in Carbognin, Laura, Gambolati, Giuseppe, and Johnson, A.I., eds., Land subsidence, vol. II, Proceedings of the Sixth International Symposium on Land Subsidence, Ravenna, Italy, 24-29 September 2000, p. 127-138.

Bell, J.W., Amelung, Falk, Ramelli, A.R., and Blewitt, Geoff, 2002, Land subsidence in Las Vegas, Nevada, 19352000: new geodetic data show evolution, revised spatial patterns, and reduced rates: Environmental \& Engineering Geoscience, v. VIII, no. 3, p. 155-174.

Bell, J.W., and Price, J.G., 1993: Subsidence in Las Vegas Valley, 1980-91, final project report: Nevada Bureau of Mines and Geology Open-File Report 93-4, 182 p.

Buckley, S.M., Rosen, P.A., Hensley, Scott, and Tapley, B.D., 2003, Land subsidence in Houston, Texas, measured by radar interferometry and constrained by extensometers: Journal of Geophysical Research, 108(B11), 2542, doi: 10.1029/2002JB001848

Chen, C.W., 2001, Statistical-cost network-flow approaches to two-dimensional phase unwrapping for radar interferometry: Stanford University, Ph.D. Dissertation, $141 \mathrm{p}$.

Costantini, Mario, 1998, A novel phase unwrapping method based on network programming: Institute of Electrical and Electronics Engineers Transactions on Geoscience and Remote Sensing, v. 36, no. 3, p. 813-821.

Curlander, J.C., and McDonough, R.N., 1991, Synthetic aperture radar, Wiley Series in Remote Sensing, New York, John Wiley, 672 p.

Ferretti, A., Prati, C., and Rocca, F., 2000, Nonlinear subsidence rate estimation using permanent scatterers in differential SAR interferometry: IEEE Transactions on Geoscience and Remote Sensing, v. 38, no. 5, p. 22022212. 
Fielding, E.J., Blom, R.G., and Goldstein, R.M., 1998, Rapid subsidence over oil fields measured by SAR interferometry: Geophysical Research Letters, v. 27, p. 3215-3218.

Gabriel, A.K., Goldstein, R.M., and Zebker, H.A., 1989, Mapping small elevation changes over large areas: Differential radar interferometry: Journal of Geophysical Research, v. 94, no. B7, p. 9183-9191.

Galloway, D.L., Hudnut, K.W., Ingebritsen, S.E., Phillips, S.P., Peltzer, G., Rogez, F., and Rosen, P.A., 1998, Detection of aquifer system compaction and land subsidence using interferometric synthetic aperture radar, Antelope Valley, Mojave Desert, California: Water Resources Research, v. 34, no. 10 , p. 2573-2585.

Galloway, D.L., Jones, D.R., and Ingebritsen, S.E., 2000, Measuring land subsidence from space: U.S. Geological Survey Fact Sheet 051-00, 4 p.

Halford, K.J., Laczniak, R.L., and Galloway, D.L., 2005, Hydraulic characterization of overpressured tuffs in central Yucca Flat, Nevada Test Site, Nye County, Nevada: U.S. Geological Survey Scientific Investigations Report 2005-5211, 36 p.

Hanssen, R.F., 2001, Atmospheric heterogeneities in ERS tandem SAR interferometry: The Netherlands, Delft University Press.

Heywood, C.E., Galloway, D.L., and Stork, S.V., 2002, Ground displacements caused by aquifer-system water-level variations observed using interferometric synthetic aperture radar near Albuquerque, New Mexico: U.S. Geological Survey Water-Resources Investigation Report 02-4235, $18 \mathrm{p}$.

Hoffmann, Jörn, 2003, The application of satellite radar interferometry to the study of land subsidence over developed aquifer systems: Stanford University, Ph.D. Dissertation, $211 \mathrm{p}$.

Hoffmann, Jörn, Galloway, D.L., and Zebker H.A., 2003, Inverse modeling of interbed storage parameters using land subsidence observations, Antelope Valley, California: Water Resources Research, 39, doi: 10.1029/2001WR001253.

Hoffmann, Jörn, Zebker, H.A., Galloway, D.L., and Amelung, Falk, 2001, Seasonal subsidence and rebound in Las Vegas Valley, Nevada, observed by synthetic aperture radar interferometry: Water Resources Research, v. 37, no. 6, p. 1551-1566.
Ikehara, M.E., Galloway, D.L., Fielding, E., Bürgmann, R., Lewis, A.S., and Ahmadi, B., 1998, InSAR imagery reveals seasonal and longer-term land-surface elevation changes influenced by ground-water levels and fault alignment in Santa Clara Valley, California [abs.]: EOS (supplement) Transactions, American Geophysical Union, no. 45, November 10, 1998, p. F37.

Jónsson, Sigurjón, 2002, Modeling volcano and earthquake deformation from satellite radar interferometric observations: Stanford University, Ph.D. Dissertation, $164 \mathrm{p}$.

Laczniak, R.J., Galloway, D.L., and Sneed, Michelle, 2003, InSAR detection of post-seismic and coseismic groundsurface deformation associated with underground weapons testing, Yucca Flat, Nevada Test Site, in Prince, K.R., and Galloway, D.L., eds., 2003, U.S. Geological Survey subsidence interest group conference, proceedings of the technical meeting, Galveston, Texas, November 27-29, 2001: U.S. Geological Survey Open-File Report 03-308, p. 121-128.

Malmberg, G.T., 1965, Available water supply of the Las Vegas ground-water basin, Nevada: U.S. Geological Survey Water-Supply Paper 1780, 116 p.

Massonnet, D., Briole, P., and Arnaud, A., 1995, Deflation of Mount Etna monitored by spaceborne radar interferometry: Nature, v. 375, p. 567-570.

Massonnet, D., and Feigl, K.L., 1998, Radar interferometry and its application to changes in the Earth's surface: Reviews of Geophysics, v. 36, p. 441-500.

Massonnet, D., Holzer, T., and Vadon, H., 1997, Land subsidence caused by the East Mesa geothermal field, California, observed using SAR interferometry: Geophysical Research Letters, v. 24, p. 901-904.

Massonnet, D., Rossi, M., Carmona, C., Adragna, F., Peltzer, G., Feigl, K., and Rabaute, T., 1993, The displacement field of the Landers earthquake mapped by radar interferometry: Nature, v. 364, p. 138-142.

Maxey, G.B., and Jameson, C.H., 1948, Geology and water resources of Las Vegas, Pahrump, and Indian Springs Valleys, Clark and Nye Counties, Nevada: Nevada State Engineer, Water Resources Bulletin 5, 121 p.

Mindling, A.L., 1971, A summary of data relating to land subsidence in Las Vegas Valley: Center for Water Resources Research, Desert Research Institute, University of Nevada, Reno, 55 p.

Pavelko, M.T., 2000, Ground-water and aquifer-systemcompaction data from the Lorenzi site, Las Vegas, Nevada, 1994-99: U.S. Geological Survey Open-File Report 00-362, $26 \mathrm{p}$. 
Poland, J.F., 1960, Land subsidence in the San Joaquin Valley and its effect on estimates of ground-water resources: International Association of Scientific Hydrology, Commission on Subterranean Waters, Publication 52, p. 324-335.

Riley, F.S., 1969, Analysis of borehole extensometer data from central California, in Tison, L.J., ed., Land subsidence, vol. 2. Tokyo International Association of Scientific Hydrology Publication 89, Merbien, p. 423-431.

Rosen, P.A., Hensley, S., Zebker, H.A., Webb, F.H., and Fielding, E., 1996, Surface deformation and coherence measurements of Kilauea volcano, Hawaii, from SIR-C radar interferometry: Journal of Geophysical Research, v. 101, p. 23,109-23,125.

Schmidt, D.A., and Bürgmann, Roland, 2003, Time dependent land uplift and subsidence in the Santa Clara Valley, California, from a large InSAR data set: Journal of Geophysical Research, 108(B9), 2416, doi:10.1029/ 2002JB002267.

Sneed, Michelle, Ikehara, M.E., Galloway, D.L., and Amelung, Falk, 2001, Detection and measurement of land subsidence using Global Positioning System and interferometric synthetic aperture radar, Coachella Valley, California, 1996-98: U.S. Geological Survey WaterResources Investigations Report 01-4193, 26 p.

Sneed, Michelle, Stork, S.V., and Ikehara, M.E., 2002, Detection and measurement of land subsidence using Global Positioning System and interferometric synthetic aperture radar, Coachella Valley, California, 1998-2000: U.S. Geological Survey Water-Resources Investigations Report 02-4239, 29 p.

Stork, S.V., and Sneed, Michelle, 2002, Houston-Galveston Bay area, Texas, from space-a new tool for mapping land subsidence: U.S. Geological Survey Fact Sheet 110-02, 6 p.
Terzaghi, Karl, 1925, Principles of soil mechanics: IV; settlement and consolidation of clay: Erdbaummechanic, 95,3, p. 874-878.

Terzaghi, Karl, 1943, Theoretical soil mechanics: New York, Wiley, 510 p.

Thatcher, W., and Massonet, D., 1997, Crustal deformation of Long Valley Caldera, eastern California, 1992-1996, inferred from satellite radar interferometry: Geophysics Research Letters v. 24, no. 20, p. 2519-2522.

Tolman, C.F., and Poland, J.F., 1940, Ground-water, salt-water infiltration, and ground-surface recession in Santa Clara Valley, Santa Clara County, California: Transactions of the American Geophysical Union, v. 21, p. 23-34.

Vadon, H., and Sigmundsson, F., 1997, Crustal deformation from 1992 to 1995 at Mid-Atlantic Ridge, Southwest Iceland, mapped by radar interferometry: Science, v. 275, no. 5297 , p. 193-197.

Valentine, D.W., Densmore, J.L., Galloway, D.L., and Amelung, Falk, 2001, Use of InSAR to identify land-surface displacements caused by aquifer-system compaction in the Paso Robles area, San Luis Obispo County, California, March to August 1997: U.S. Geological Survey Open-File Report 00-447, poster report.

Wicks, Charles, Jr., Thatcher, Wayne, and Dzurisin, Daniel, 1998, Migration of fluids beneath Yellowstone Caldera inferred from satellite radar interferometry: Science, v. 282, p. 458-462.

Zebker, H.A., Rosen, P.A., Goldstein, R.M., Gabriel, A., and Werner, C.L., 1994, On the derivation of coseismic displacement fields, using differential radar interferometry-The Landers earthquake: Journal of Geophysical Research, v. 99, no. B10, p. 19,617-19,634. 
Interferograms Showing Land Subsidence and Uplift in Las Vegas Valley, Nevada, 1992-99

This page left intentionally blank 


\section{Appendix A. Instructions for Interactive Map}

The appendix is available in Portable Document Format (PDF) for download at URL: http://pubs.water.usgs.gov/ sir2006-5218.

If you do not have the Adobe Acrobat PDF Reader, it is available for free download from Adobe Systems Incorporated at URL: http://www.adobe.com.

The interactive map allows users to browse and compare the 44 individual interferograms, the three-color stacked interferogram, and two Landsat images side by side. Both sides of the viewer can display any of the 91 images. To display an image, select the desired interferogram or Landsat image from the appropriate drop-down menu. To see major freeways, selected faults, or areas of interest (subsidence bowls and areas of recurring localized deformation), check one or more of the corresponding boxes.
The viewer allows for three fundamental types of visual analyses. First, identify patterns of deformation and decorrelated areas by comparing three-color and multicolored pairs. Second, observe temporal changes by comparing interferograms from different times. Third, determine land or water uses by identifying areas of deformation on an interferogram and comparing the interferogram to a Landsat image. For more information on interpreting interferograms and Landsat images, see the "Interpreting Interferograms" section of this report. 
For more information concerning the research in this report, contact the Director, Nevada Water Science Center

U.S. Geological Survey

2730 North Deer Run Road

Carson City, Nevada 89701

http://nv.water.usgs.gov 


$$
\text { ख़ }
$$

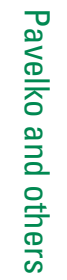

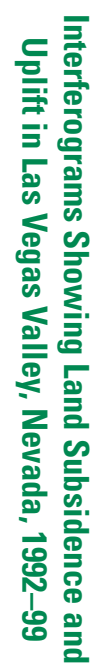

